\title{
New benthopelagic aetideids (Crustacea: Copepoda: Calanoida) from deep Antarctic waters
}

\author{
Elena L. Markhaseva ${ }^{1}$, Knud Schulz ${ }^{2}$ \\ ${ }^{1}$ Zoological Institute, Russian Academy of Sciences, Universitetskaya nab. 1, St. Petersburg \\ 199034, Russia. \\ e-mail: copepoda@zin.ru \\ ${ }^{2}$ DZMB-Senckenberg, Biozentrum Grindel \& Zoologisches Museum, Martin-Luther-King-Platz 3, \\ Hamburg D-20146, Germany. \\ e-mail:kschulz@zoologie.uni-hamburg.de
}

\begin{abstract}
Three new and one rare benthopelagic aetideid species of Bradyetes and Pseudeuchaeta are described from female specimens collected during the German expeditions ANDEEP I-III in 2002 and 2005 from bathy- and abyssopelagic depths above the sea bed. Pseudeuchaeta acuticornis sp.n. is distinguished from congeners by 5 setae on the second endopodal segment of mandible, presence of lateral spine on the first exopodal segment of P1 and 3 setae on the maxillule coxal endite. P. acuticornis is the second representative of the genus found in high Antarctic waters. Bradyetes weddellanus sp.n. differs from the other species of the genus by, among other states, a very small sensory appendage on the syncoxa of maxilliped, a short lateral spine of P1 exopod segment 2 , one additional seta on the distal segment of antennule. Bradyetes curvicornis sp.n. is distinguished from congeners by the number of setae on the second endopodal segment of mandible and maxillulary endopod and a very long sensory appendage on the syncoxa of maxilliped. Within Bradyetes both new species are distinctly larger than their congeners. Furthermore, present collections yielded female specimens of Bradyetes cf. inermis from the South Atlantic and in the Southern Ocean; these are the first records for Bradyetes from the southern hemisphere.
\end{abstract}

KEYWORDS: copepods, Aetideidae, Bradyetes, Pseudeuchaeta, benthopelagic, Weddell Sea.

\section{Новые глубоководные бентопелагические Aetideidae (Crustacea: Copepoda: Calanoida) из Антарктики}

\author{
Е.Л. Мархасева ${ }^{1}$, Кнуд Шульц ${ }^{2}$ \\ 'Зоологический институт РАН, Университетская наб. 1, Санкт-Петербург 199034, Россия. \\ e-mail: copepoda@zin.ru \\ ${ }^{2}$ DZMB-Senckenberg, Biozentrum Grindel \& Zoologisches Museum, Martin-Luther-King-Platz 3, \\ D-20146, Germany. \\ e-mail:kschulz@zoologie.uni-hamburg.de
}

РЕЗЮМЕ: Представлены описания самок трех новых и одного редкого вида бентопелагических Aetideidae Bradyetes и Pseudeuchaeta. Экземпляры собраны Германскими экспедициями ANDEEP I-III в 2002 и 2005 годах над поверхностью дна с батии абиссопелагических глубин. Pseudeuchaeta acuticornis sp.n. отличается от других 
видов рода наличием 5 щетинок на втором сегменте эндоподита мандибулы, присутствием наружного шипа на первом сегменте Р1 и 3 щетинками на коксальном эндите максиллулы. P. acuticornis, второй вид Pseudeuchaeta, найденный в высоких широтах Антарктики.Bradyetes weddellanussp.n. отличается от остальных видов рода очень малым размером сенсорного придатка на коксальном эндите синкоксы максиллипеды, коротким наружным шипом второго сегмента экзоподита P1, одной дополнительной щетинкой на дистальном сегменте антеннулы и некоторыми другими чертами строения. Bradyetes curvicornis sp.n. характеризуется числом щетинок на втором сегменте эндоподита мандибулы и эндоподите максиллулы и наличием очень длинного сенсорного придатка на синкоксе максиллипеды. Оба вида больше по размерам, чем остальные виды рода. Кроме того, в изученном материале найдены четыре самки Bradyetes cf. inermis из Южной Атлантики и Южного Океана. Род Bradyetes впервые отмечен в Южном полушарии.

КЛЮЧЕВЫЕ СЛОВА: копеподы, Aetideidae, Bradyetes, Pseudeuchaeta, бентопелагические, море Уэдделла.

\section{Introduction}

Recent studies of benthopelagic/hyperbenthic calanoid copepods from the Southern Ocean show that the near-bottom calanoid fauna includes many new genera and species (Bradford, Wells, 1983; Ohtsuka et al., 1998; Schulz, 1996, 1998, 2002, 2005; Schulz, Markhaseva, 2000; Markhaseva, Dahms, 2004). Three new and one rare benthopelagic species of two aetideid genera were found in the samples collected during the German expeditions ANDEEP I-III in 2002 and 2005 in the Scotia and Weddell Sea of the Southern Ocean, where an intensive benthopelagic sampling programme by an epibenthic sledge was undertaken (Brandt et al., 2004). Representatives of the genera Bradyetes and Pseudeuchaeta are mainly benthopelagic, and up to now only $P$. brevicauda Sars, 1905 was recorded from the southern hemisphere (to about $\left.60^{\circ} \mathrm{S}\right)$ (Markhaseva, 1996). Present collections of $P$. acuticornis are considered the second and, moreover, the southernmost record of the genus in the Southern Ocean. The genus Bradyetes is reported for the first time in the Southern Ocean.

In addition to the above mentioned genera, two other exclusively benthopelagic aetideid genera recently have been recorded from the Antarctic near-bottom fauna: Parabradyidius
(Schulz, Markhaseva, 2000) and Comantenna (Schulz, 2002). Three more aetideid species are described below, bringing to five the number of species in the genus Bradyetes and to seven the species in Pseudeuchaeta.

\section{Methods and Terminology}

Four aetideid species of two genera were collected during $\mathrm{R} / \mathrm{V}$ Polarstern expeditions ANDEEP I-II in 2002 and ANDEEP III in 2005. Sampling was done close to the sea bed at bathypelagic and abyssal depths between 1030 and $4725 \mathrm{~m}$ in the Scotia and the Weddell Sea of the Southern Ocean by a closing epibenthic sledge (Brandt, Barthel, 1995) with both supranet (sampling layer ca. 1.00-1.30 $\mathrm{m}$ above the bottom; mesh size $0.3 \mathrm{~mm}$ ) and epinet subsamples (0.27-0.60 $\mathrm{m}$ above the bottom; mesh size $0.5 \mathrm{~mm}$ ). Specimens were fixed in $96 \%$ ethanol and later stained by adding a solution of chlorazol black E dissolved in 70\% ethanol / 30\% water. Oral parts and swimming legs were dissected and figures were done in glycerin using a camera lucida.

The following abbreviations are used in the descriptions: P1-P4, swimming legs 1-4. Free segments of antennule are designated by Arabic numerals, ancestral segments by Roman nume- 
rals. One seta and one aesthetasc on a segment of the antennule are designated: 1s + 1ae; "1?" indicates that a setal element was broken so that its identity on antennule could not be determined and only the scar at the location of its attachment was counted. Segmentation of antenna is assumed as having an 11-segmented exopod (Schulz, 2005); the maxilliped syncoxa is considered having 3 praecoxal endites and 1 coxal endite (Ferrari, Markhaseva, 2000a,b; Ferrari, Ivanenko, 2001).

\section{Taxonomy}

\section{Bradyetes weddellanus sp.n.}

Figs 1-3.

Material. Holotype, adult female, undissected, body length $5.10 \mathrm{~mm}$ (ZMH K-41163). Weddell Sea, 71 ${ }^{\circ} 18^{\prime}$ S, $13^{\circ} 58^{\prime} \mathrm{W}$, station 074-6, epinet, 20.02.2005, above the sea bed at depths 1053-1030 m.

Paratypes: 9 females, body length $4.75-5.50 \mathrm{~mm} .6$ females, (ZMH K-41164) and 3 females, (ZIN 91065), collection data as for holotype.

The holotype and 6 paratypes are deposited at the Zoological Museum Hamburg, University of Hamburg, 3 paratypes are deposited at the Zoological Institute, Russian Academy of Sciences, St. Petersburg (ZIN).

Additional material. One female, collected at station 132-2, epinet, 06.03.2002, above the sea bed at depth $2084 \mathrm{~m}$, Weddell Sea, 65017' S, 5322' W; one female collected at station 141-10, supranet, 23.03.2002, above the sea bed at depth 2281-2258m, Scotia Sea, $58^{\circ} 24^{\prime} \mathrm{S}, 25^{\circ} 01^{\prime} \mathrm{W}$.

Description. Adult female, total length 4.75$5.50 \mathrm{~mm}$; prosome 2.6-2.9 times longer than urosome. Rostrum as a blunt plate without filaments (Fig. 1B-C). Cephalosome and pediger 1 fused and pedigers 4 and 5 fused; posterior corners as short rounded lobes (Fig. 1A-B, D). Spermathecae narrow ventrally, widening dorsally to varying degree in different specimens (Fig. 1D). Caudal rami with 4 terminal setae, 1 ventral seta (Fig. 1E) and a small subterminal seta (Fig.1B, E).

Antennule as long as prosome or exceeding prosome by distal segment. Antennule (Fig. 1F-I), of 24 free segments, armature as follows: I -1 s, II-IV $-2 \mathrm{~s}+[2 \mathrm{~s}+1 \mathrm{ae}]+2 \mathrm{~s}, \mathrm{~V}$ to IX $-2 \mathrm{~s}$ each, $\mathrm{X}-\mathrm{XI}-4 \mathrm{~s}$, XII to XX $-2 \mathrm{~s}$ each, XXI $-2 \mathrm{~s}+1 \mathrm{ae}, \mathrm{XXII}$ to XXIII - 1s each, XXIV to XXVI -2 s each, XXVII-XXVIII $-4 s+1$ ae +1 small spine-like seta situated near base of aesthetasc (Fig. 1I).

Antenna (Fig. 3A, B), coxa with 1 seta, basis with 2 setae, exopod 8-segmented with 2, 2, 1, 1, 1, 1,1 (vestigial) and 3 setae; exopod slightly longer (about 1.1 times) than endopod; first endopodal segment with 2 setae, second with 8 and 7 or 8 setae as intrespecific variation.

Mandible (Fig. 1J-M), gnathobase with 5 large and 2 small teeth plus dorsal seta; basis with 1 seta, exopod of 5 segments with 1, 1, 1, 1 and 2 setae; endopod segment 1 with 1 seta, segment 2 with 4 setae.

Maxillule (Fig. 2B-E), praecoxal endite with 9 long and 2 small setae, length of smaller setae varies, sometimes one much smaller (Fig. 2D-E), coxal endite with 4 setae; proximal basal endite with 2 long and 1 short setae; distal basal endite with 4 setae, 1 of them longer and thicker than others; endopod with 12 setae; exopod with 11 setae; coxal epipodite with 9 setae.

Maxilla (Fig. 2A), praecoxal and proximal coxal endites with 3 setae each; proximal basal endite with 3 setae, of these 1 thicker and more sclerotized, spine-like; distal basal endite plus ramus with 8 setae: 6 long and 2 small setae. Praecoxal and coxal endites with short surface spinules.

Maxilliped (Fig. 2F-H), syncoxa with 1 seta on proximal praecoxal endite, 2 setae on middle endite, 3 setae and rows of surface spinules on distal praecoxal endite; coxal endite with 3 setae and small sensory appendage. Basis with 3 medial and 2 distal setae. Endopod of five segments with 4, 4, 3, 3+1 and 4 setae.

P1 (Fig. 3C-E), coxa without seta, basis with small distolateral seta, medial distal seta curved; endopod 1-segmented with poorly developed lateral lobe ornamented with denticles, and patch of denticles on anterior surface. Size of denticles on lateral lobe varies in different specimens (Fig. 3C, E). Exopod segments 1,2 and 3 with 1 lateral spine each; spine of exopod segment 1 reaching close to midlength of following spine, spine of exopod segment 2 not reaching base of following spine. Spines of exopod segments 1 and 2 densely pubescent on internal surface.

P2 (Fig. 2F), coxa with medial seta; basis without seta; endopod of 2 segments; exopod of $3 \mathrm{seg}$ ments, lengths of outer spines as figured.

P3-P4 (Fig. 2G-H), coxa with medial seta, basis without seta; endopod and exopod of 3 segments.

Male unknown.

Etymology. The species epithet is given for the type locality in the Weddell Sea. Gender masculine.

Remarks. Bradyetes includes 3 species: $B$. inermis Farran, 1905, B. pacificus Ohtsuka, Boxshall et Shimomura, 2005 and deviating in the setation of mandibular palp, maxillule and maxilla (see Table 1) species B. matthei Johannessen, 1976. The new species $B$. weddellanus fits well the generic definition, but differs from congeners by i) larger size (less than $4.15 \mathrm{~mm}$ for remaining species); ii) a very small sensory appendage on coxal endite of maxilliped syncoxa (shares with $B$. matthei, Table 1); iii) a short 


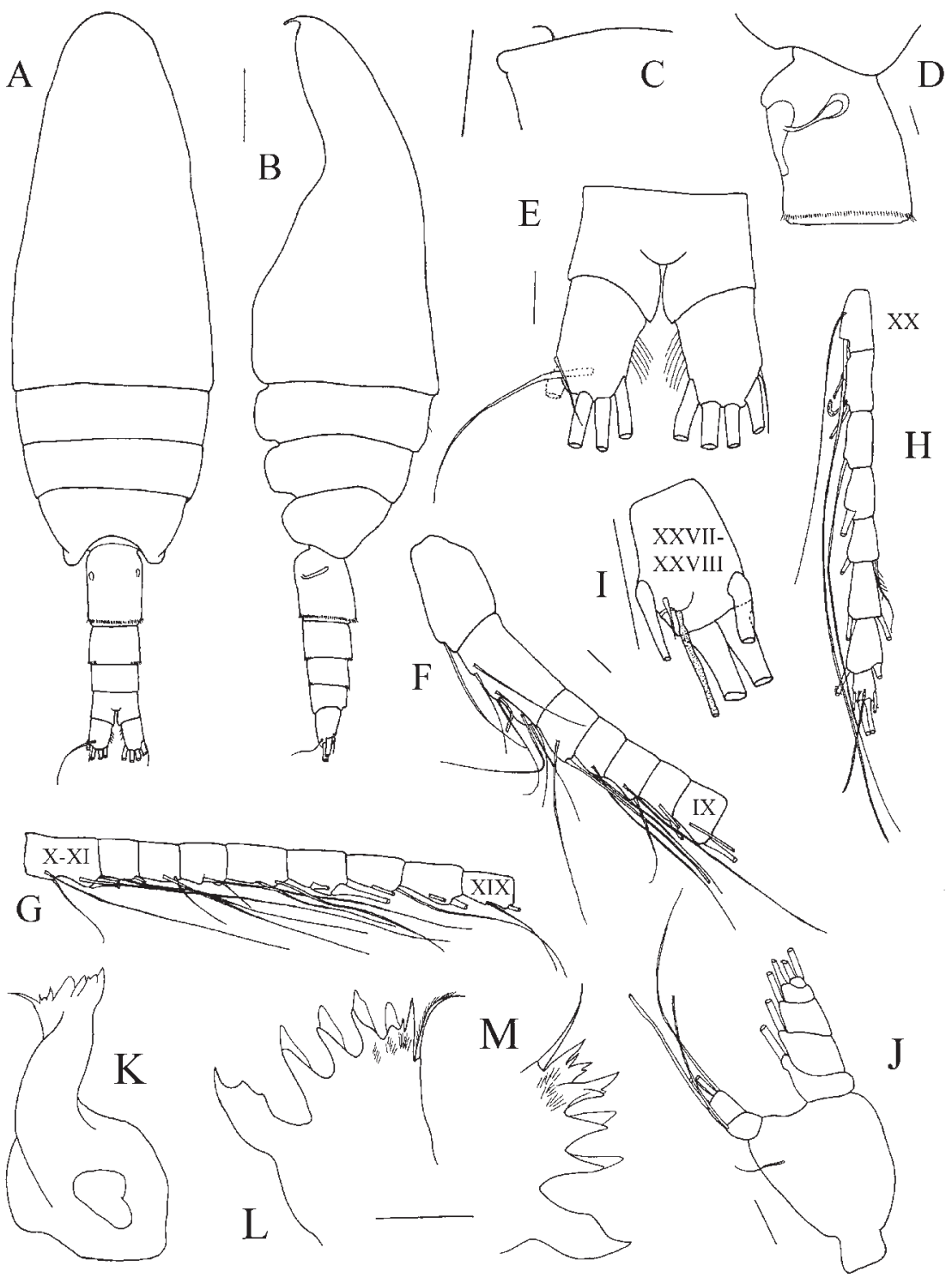

Fig. 1. Bradyetes weddellanus sp.n. Female, paratype.

A - habitus, dorsal; B - habitus, left lateral view; C - rostrum, left lateral view; D - posterior prosome and genital double-somite, left lateral view; E - anal segment and caudal rami, dorsal view (right ventral seta broken). F — antennule, segments I (1st) to IX (7th), segment 2 is a complex of ancestral segments II-IV; G - antennule, segments X (8th) - XIX (16th); H - antennule, segments XX (17th) to XXVIII (24th), segment 24 is a complex of ancestral segments XXVIIXXVIII; I — antennule, distal segment XXVII - XXVIII (24th); J — mandibular palp; K — mandibular gnathobase; L, $\mathrm{M}$ - cutting edge of mandibular gnathobase (different limbs). Scales: A, B $-0.5 \mathrm{~mm}$, remaining figures $0.1 \mathrm{~mm}$.

Рис. 1. Bradyetes weddellanus sp.n. Самка, паратип.

А - общий вид, вид со спины; В - общий вид, слева; C - рострум, слева; D - задняя часть просомы и генитальный сомит, слева; E - анальный сомит и каудальные ветви, вид со спины (правая вентральная щетинка сломана). F - антеннула, сегменты с I (1-го) по IX (7-й), сегмент 2 - комплекс анцестральных сегментов II-IV; G - антеннула, сегменты X (8-й) - XIX (16-й); H - антеннула, сегменты XX (17-й) - XXVIII (24-й), сегмент 24 — комплекс анцестральных сегментов XXVII-XXVIII; I — антеннула, дистальный сегмент XXVII - XXVIII (24й); J — щупик мандибулы; K — гнатобаза мандибулы; L, M — жующий край мандибулы (разные конечности). Масштаб: A, В - 0,5 мм, остальные рисунки - 0,1 мм. 


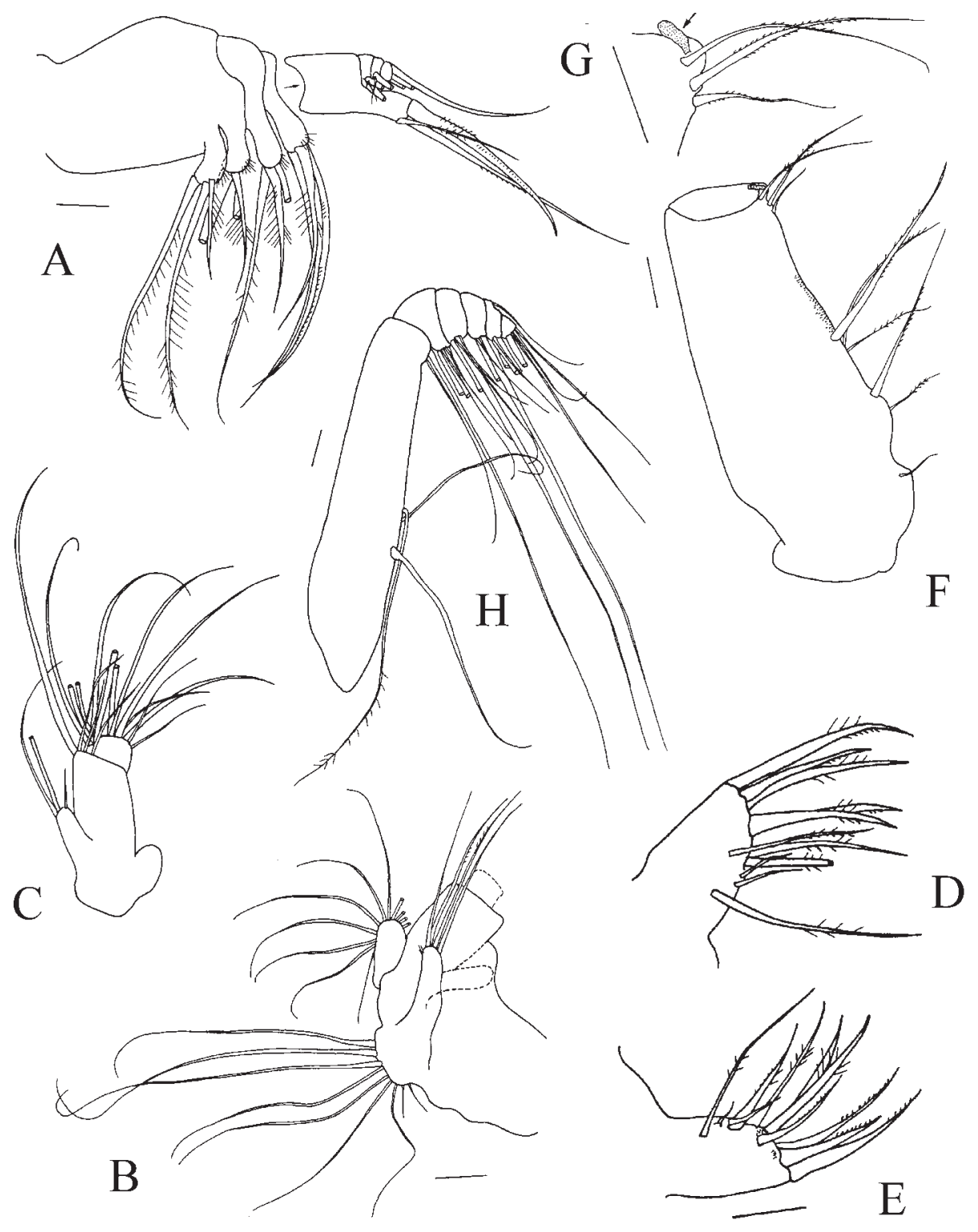

Fig. 2. Bradyetes weddellanus sp.n. Female.

A - maxilla; B - maxillule, setation figured for coxal epipodite, coxal endite and exopod ; $\mathrm{C}$ - maxillule, basal endites and endopodite; D, E - maxillule, praecoxal endite (different specimens); F — syncoxa of maxilliped; G — coxal endite of syncoxa of maxilliped (arrow indicates sensory appendage); $\mathrm{H}$ - maxilliped, basis and endopod. [D, female of station 141-10, remaining details: paratype]. Scales: $0.1 \mathrm{~mm}$.

Рис. 2. Bradyetes weddellanus sp.n. Самка.

А - максилла; В - максиллула, вооружение изображено для коксального эпиподита, коксального эндита и экзоподита; $\mathrm{C}$ - максиллула, базальные эндиты и эндоподит; D, E - максиллула, прекоксальный эндит (разные экземпляры); F — синкокса максиллипеды; G — коксальный эндит синкоксы максиллипеды (стрелка указывает на сенсорный придаток); H — максиллипеда, базис и эндоподит. [D, самка со станции 141-10, остальные детали: паратип]. Масштаб 0,1 мм. 


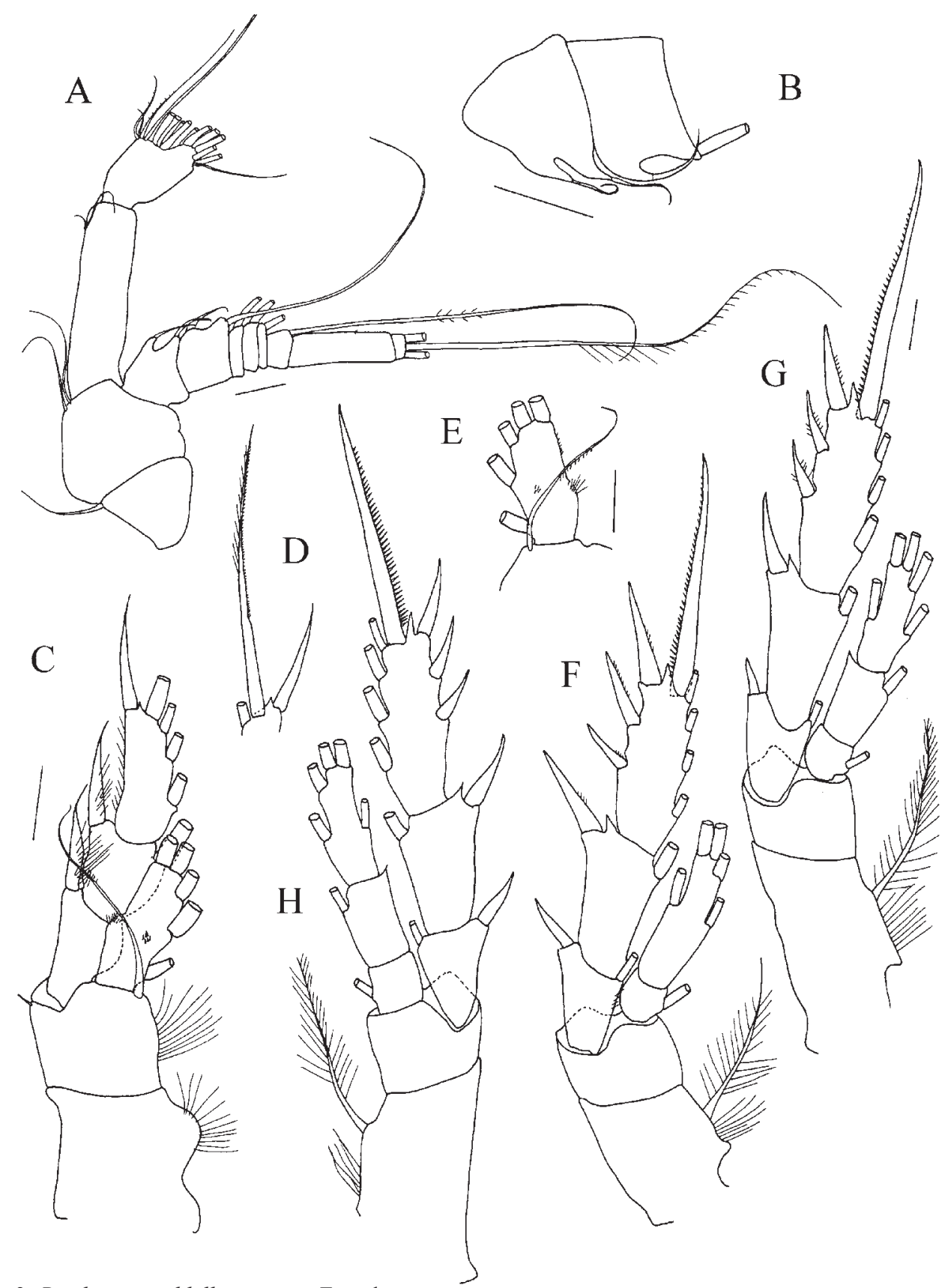

Fig. 3. Bradyetes weddellanus sp.n. Female.

A - antenna; B - proximal segments of antenna exopod; C - P1, anterior; D - P1, distal part of exopod segment 3; $\mathrm{E}-\mathrm{P} 1$, anterior, distal part of basis and endopod; $\mathrm{F}-\mathrm{P} 2$, anterior; $\mathrm{G}-\mathrm{P}$ 3, anterior; $\mathrm{H}-\mathrm{P} 4$, anterior. $\mathrm{E}$, of female from station $141-10$, remaining details of paratype. Scales: $0.1 \mathrm{~mm}$.

Рис. 3. Bradyetes weddellanus sp.n. Самка.

А — антенна; В — проксимальные сегменты экзоподита антенны; C - P1, вид спереди; D — P1, дистальная часть третьего сегмента экзоподита; E - P1, вид спереди, дистальная часть базального членика и эндоподит; F - P2, вид спереди; G - Р3, вид спереди; Н - Р4, вид спереди. [Е, самка со станции 141-10, остальные детали: паратип]. Масштаб 0,1 мм. 
lateral spine on P1 exopodal segment 2 (this spine longer in remaining species, Table 1); iv) presence of a small fifth spine-like seta on the distal segment of antennule (absent in other species of the genus); v) presence of a short lateral spine on P3 exopodal segment 1 (shared with $B$. curvicornis, Table 1); vi) rounded posterior corners of prosome (shares with $B$. inermis s.1.); vii) a poorly developed lateral endite of P1 endopod (shared with $B$. inermis sensu Farran (1905) and B. cf. inermis (Fig. 5A-D, I and Table 1).

\section{Bradyetes curvicornis sp.n.}

Fig. 4.

Material. Holotype, adult female, dissected, body length $4.14 \mathrm{~mm}$ (ZMH K-41167).

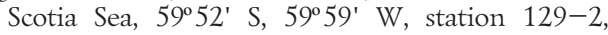
epinet, 23.02.2002, above the sea bed at depths 3643$3622 \mathrm{~m}$. The holotype is deposited at the Zoological Museum Hamburg, University of Hamburg.

Description. Adult female, total length 4.15 $\mathrm{mm}$; prosome 3.35 times longer than urosome. Rostrum as a blunt plate without filaments. Cephalosome and pediger 1 separate, pedigers 4 and 5 separate dorsally and fused laterally; posterior corner ending in short point directed dorsodistally (Fig. 4A-D). Spermathecae narrow, slightly wider in dorsal part (Fig. 4D). Caudal rami with 4 terminal setae, 1 ventral seta (Fig. 4C) and a small lateral subterminal seta; two terminal setae not shown in figure.

Antennule reaching to posterior end of genital double-somite, of 24 free segments, armature differs from $B$. weddellanus in setation of distal segment (XXVII-XXVIII) as $4 \mathrm{~s}+1 \mathrm{ae}$, small spine-like seta absent.

Antenna (Fig. 4E), coxa with 1 seta, basis with two setae, exopod of 8 free segments with 2, 2, 1, 1, $1,1,1$ (vestigial) and 3 setae, exopod nearly as long as endopod; first endopodal segment with 2 setae, second with 8 and 7 setae.

Mandible similar to that of $B$. weddellanus, but with 5 setae (instead of 4 ) on endopod segment 2 (Table 1).

Maxillule endopod with 14 setae, 8 of these thick, long and strongly sclerotized; in other characters as in $B$. weddellanus (Table 1).

Maxilla similar to that of $B$. weddellanus.

Maxilliped (Fig. 4F) coxal endite of syncoxa with very long sensory appendage; in other features as in B. weddellanus (Table 1).

P1 (Fig. 4G), endopod with group of denticles on anterior surface near base of second medial seta; lateral lobe well developed, ornamented with denticles; lateral spines of exopod segments 1 and 2 curved distally; lateral spine of segment 3 thinner and longer than spines of segments 1 and 2; spines of exopod segments 1 and 2 pubescent on inner surface.
P2-P4 similar to those of B. weddellanus.

Male unknown.

Etymology. The species epithet is given for the posterior horn-like corners of prosome curved posteriodorsally. Gender masculine.

Remarks. The new species is a large-sized species like $B$. weddellanus (all remaining congeners are smaller, Table 1).B. curvicornis is distinguished from other species of the genus by: i) 5 setae on the second endopodal segment of mandible $(3,4$ or 9 setae in congeners, Table 1); ii) 14 setae on maxillule endopod (12 or 15 setae in other species of Bradyetes, Table 1); iii) a very long sensory appendage of coxal endite on the syncoxa of maxilliped (Fig. 4F, Table 1).

\section{Bradyetes cf. inermis}

Fig. 5.

Material. 1 female, South Atlantic, $41^{\circ} 08^{\prime} \mathrm{S}, 09^{\circ} 56^{\prime} \mathrm{E}$, station 016-10, supranet, 26.01.2005, above the sea bed at depths $4725-4469 \mathrm{~m} ; 3$ females from stations 046-7, supranet, and 140-9, supranet, Southern Ocean $\left(60^{\circ} 38^{\prime} \mathrm{S} 53^{\circ} 57^{\prime} \mathrm{W}\right.$ and $58^{\circ} 16^{\prime} \mathrm{S}, 24^{\circ} 54^{\prime} \mathrm{W}$, respectively), 30.01 and 22.03 .2002 above the sea bed at depths between 2889 and $3005 \mathrm{~m}$.

Description. Adult female, total length 2.95 $\mathrm{mm}$; prosome 3.20 times longer than urosome.

Rostrum as a blunt plate without filaments (Fig. $5 \mathrm{E})$. Cephalosome and pediger 1 fused to the cephalosome, pedigers 4 and 5 separate; posterior corners of prosome rounded (Fig. 5A-D). Caudal rami with 4 terminal setae, 1 ventral seta and a small lateral subterminal seta; some setae broken and not shown in Fig. 5C.

Antennule slightly exceeding posterior border of genital double-somite.

Antenna (Fig. 5F), basis with 2 setae, exopod of 8 free segments with 2, 2, 1, 1, 1, 1, 0 and 3 setae, exopod about 1.1 times longer than endopod; first endopodal segment with 2 setae, second with 8 and 7 setae.

Mandible similar to $B$. weddellanus (Table 1).

Maxillule praecoxal arthrite with 10 setae, proximal basal endite with 1 very long seta: epipodite with only 7 intact setae; other characters as in $B$. weddellanus (Table 1).

Maxilla similar to $B$. weddellanus.

Maxilliped (Fig. 5H) coxal endite of syncoxa with sensory appendage nearly 1.5 times longer than longest distal seta (Fig. 5H, Table 1); basis and endopod similar to $B$. weddellanus.

P1 (Fig. 5I), medial seta of basis not curved or recurved; lateral lobe of endopod poorly developed, lacking denticles; anterior surface of endopod without denticles; lateral spine of exopod segment 1 extending to distal third of lateral spine 2; lateral spine of segment 2 extending beyond base of lateral spine 3. Spines of exopod segments 1 and 2 pubescent on inner surface. 


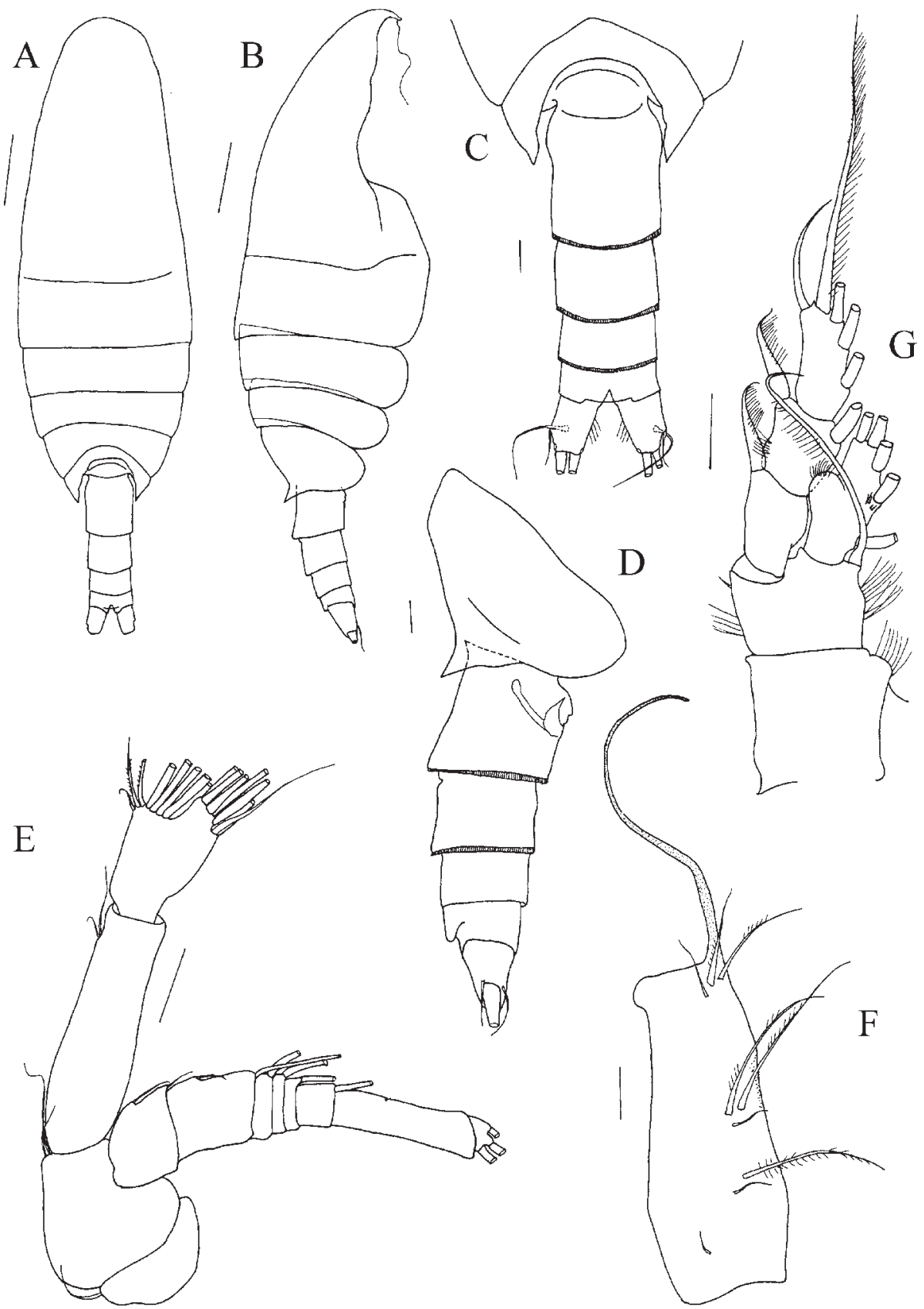

Fig. 4. Bradyetes curvicornis sp.n. Female, holotype.

A - habitus, dorsal; B — habitus, right lateral view; $\mathrm{C}$ - posterior prosome and urosome, dorsal view; D - posterior prosome and urosome, right lateral view; E - antenna; F - syncoxa of maxilliped; G - P1. Scales: A, B - $0.5 \mathrm{~mm}$, remaining figures $0.1 \mathrm{~mm}$.

Рис. 4. Bradyetes curvicornis sp.n. Самка, голотип.

А - общий вид, вид со спины; В - общий вид, справа; С - задняя часть просомы и уросома, вид со спины; D - задняя часть просомы и уросома, справа; E - антенна; F - синкокса максиллипеды; $\mathrm{G}$ - P1. Масштаб: A, В - 0,5 мм, остальные детали - 0,1 мм. 


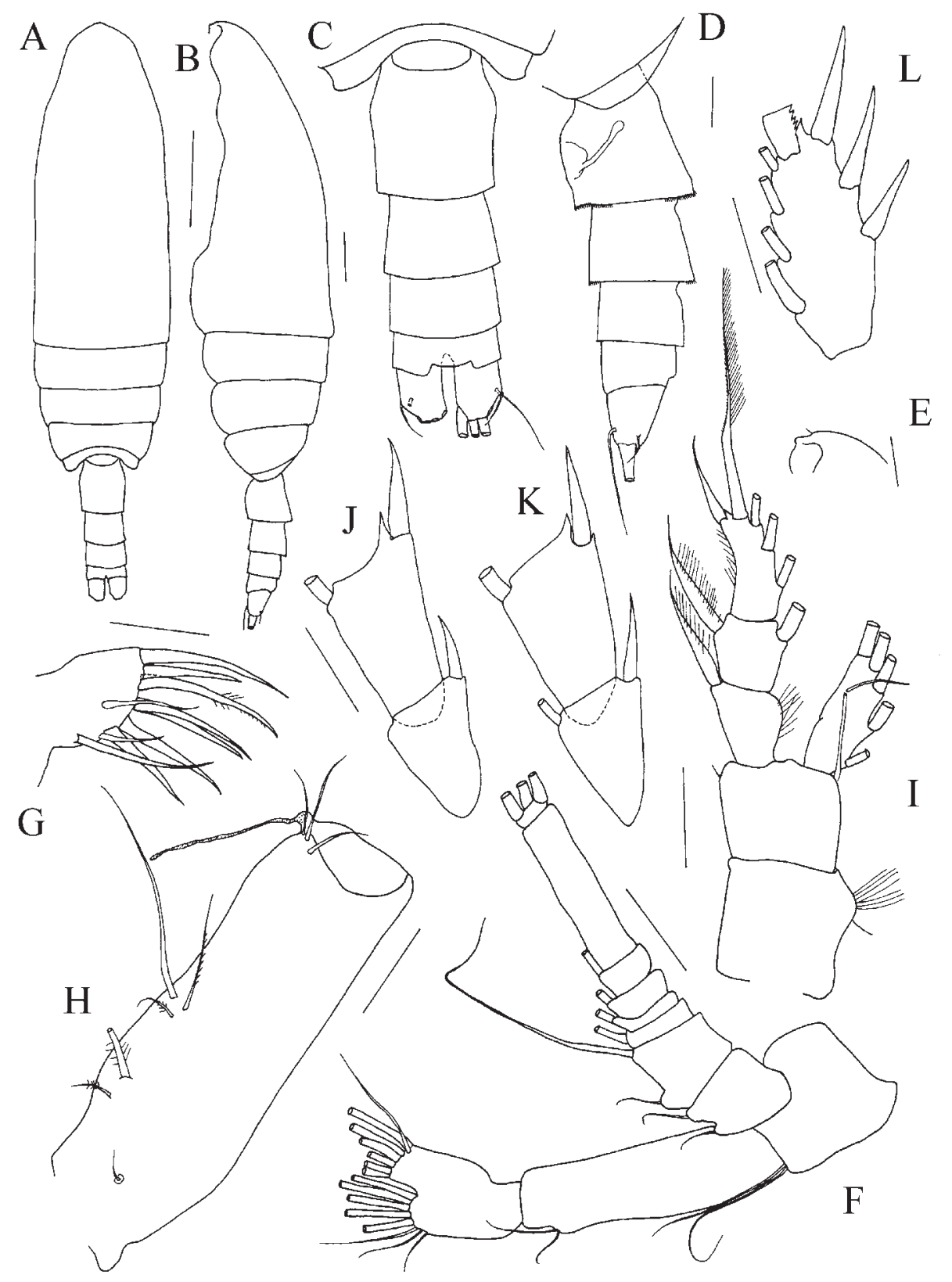

Fig. 5. Bradyetes cf. inermis. Female.

A - habitus, dorsal; B - habitus, left lateral view; C - posterior prosome and urosome, dorsal view; D - posterior prosome and urosome, left lateral view; E — rostrum, left lateral view; F — antenna; G - maxillule, praecoxal arthrite; $\mathrm{H}-$ maxilliped, syncoxa; $\mathrm{I}-\mathrm{P} 1 ; \mathrm{J}-\mathrm{P}$, exopodal segments 1 and $2 ; \mathrm{K}-\mathrm{P} 4$, exopodal segments 1 and 2 ; $\mathrm{L}-\mathrm{P} 2$, exopodal segment 3. Scales: A, B $-0.5 \mathrm{~mm}$, remaining figures $0.1 \mathrm{~mm}$.

Рис. 5. Bradyetes cf. inermis. Самка.

A - общий вид, вид со спины; В - общий вид, слева; C - задняя часть просомы и уросома, вид со спины; $\mathrm{D}$ - задняя часть просомы и уросома, слева; E — рострум, слева; F — антенна; $\mathrm{G}$ - максиллула, прекоксальный артрит; Н - максиллипеда, синкокса; I - P1; J - P3, сегменты экзоподита 1 и $2 ; \mathrm{K}-\mathrm{P} 4$, сегменты экзоподита 1 и 2; L - P2, третий сегмент экзоподита. Масштаб: А, B - 0,5 мм, остальные детали - 0,1 мм. 

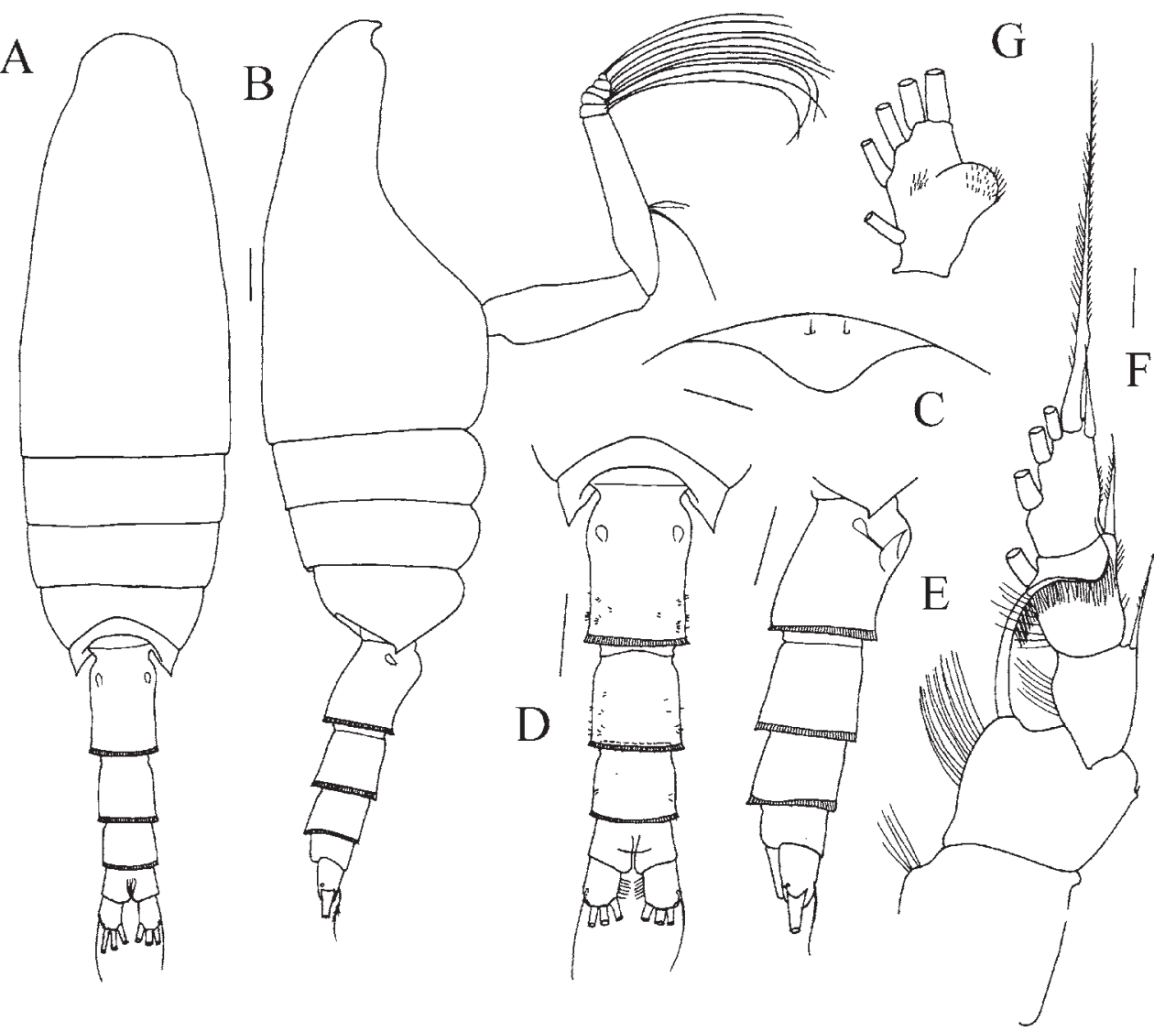

Fig. 6. Pseudeuchaeta acuticornis sp.n. Female, holotype.

A - habitus, dorsal; B - habitus, right lateral view; C - rostrum, ventral view; D - posterior prosome and genital double-somite, dorsal view; E - posterior prosome and genital double-somite, right lateral view (small dorsal subterminal seta broken); F-P1 (endopod omitted); G-P1 endopod. Scales: A-D, D-E - $0.5 \mathrm{~mm}$, remaining figures $0.1 \mathrm{~mm}$.

Рис. 6. Pseudeuchaeta acuticornis sp.n. Самка, голотип.

А - общий вид, вид со спины; В - общий вид, справа; C - рострум, вентрально; D - задняя часть просомы и генитальный сомит, вид сзади; Е - задняя часть просомы и генитальный сомит, справа (маленькая дорсальная субтерминальная щетинка сломана); F - P1 (без эндоподита); G - P1 эндоподит. Масштаб: A-B, D-E - 0,5 мм, остальные детали 0,1 мм.

P2 (Fig. 5L), lateral spines of exopod segment 3 about subequal in size, other characters as in $B$. weddellanus.

P3 (Fig. 5J) outer distal spine of exopodal segment 2 about 1.5 times longer than spine of exopodal segment 1. P4 (Fig. 5K) outer distal spine of exopodal segment 2 about 1.1 times longer than spine of exopodal segment 1 . Other characters of swimming legs similar to those of $B$. weddellanus (Table 1).

Remarks. $B$. inermis was originally described by Farran (1905) from a single female from the northwestern coast of Ireland. Grice (1972) recorded males and females from the NW Atlantic and the male of $B$. inermis was the first male of the genus to be described.
The species was also reported from Madeira in the NE Atlantic by Vives (1982) who did not provide any figures. Farran (1905) gave the size of the female as $2.57 \mathrm{~mm}$, while Grice (1972) reported the length of females ranging between 3.00 and $3.20 \mathrm{~mm}$. However, up to now descriptions of $B$. inermis are not very detailed and suffer from some inconsistencies, i.e. the lateral lobe of P1 endopod is figured as being welldeveloped by Grice (1972: Fig. 10), but it is poorlydeveloped in drawings by Farran (1905). The present specimens from the Southern Ocean are considered Bradyetes cf. inermis until the type specimens can be redescribed or specimens from the type locality in the $\mathrm{N}$ Atlantic have been described. 


\section{Pseudeuchaeta acuticornis sp.n.} Figs 6-8.

Material. Holotype, adult female, partly dissected, body length $8.10 \mathrm{~mm}$ (ZMH K- 41166) Weddell Sea, $67^{\circ} 31^{\prime} \mathrm{S}, 00^{\circ} 00^{\prime} \mathrm{E}$, station 059-5, supranet, 14.02.2005, above the sea bed at depths 4655-4651 m. The holotype is deposited at the Zoological Museum Hamburg, University of Hamburg.

Description. Adult female, total length $8.10 \mathrm{~mm}$; prosome 2.3 times longer than urosome. Rostrum as a blunt plate without filaments (Fig. 6C). Cephalosome and pediger 1 fused and pedigers 4 and 5 fused laterally and separate dorsally; posterior corners pointed (Fig. 6A-B, D-E). Spermathecae narrow ventrally and oblong-globular dorsally (Fig. 6E). Caudal rami with 4 terminal setae, 1 ventral seta and a small dorsolateral subterminal seta (Fig. 6D-E).

Antennule extending to distal part of pediger3. Antennule (Fig. 7A-E), of 24 free segments, armature as follows: I- $1 \mathrm{~s}, \mathrm{II}-\mathrm{IV}-2 \mathrm{~s}+[2 \mathrm{~s}+1 \mathrm{ae}]+2 \mathrm{~s}$, $\mathrm{V}-2 \mathrm{~s}+1 \mathrm{ae}, \mathrm{VI}$ toVII $-2 \mathrm{~s}$ each, IX $-1 \mathrm{~s}, \mathrm{X}-\mathrm{XI}$ $-4 \mathrm{~s}+1 \mathrm{ae}, \mathrm{XII}-1 \mathrm{~s}, \mathrm{XIII}-2 \mathrm{~s}, \mathrm{XIV}-2 \mathrm{~s}+1 \mathrm{ae}, \mathrm{XV}$ toXX - 2s each, XXI - 1s + 1ae, XXII toXXIII 1 s each, XXIV to XXVI - 2 s each, XXVII-XXVIII $-4 \mathrm{~s}+1 \mathrm{ae}$

Antenna (Fig. 7F), coxa with 1 seta, basis with 1 seta, exopod of 9 free segments (second and third segments partly fused), with $2,1,1,1,1,1,1,0$ and 3 setae; exopod nearly as long as endopod; first endopodal segment without seta, second with 8 and 6 setae.

Mandible (Fig. 7G-I), gnathobase with 6 strong teeth plus seta; basis with 1 seta, exopod of 5 segments with 1, 1, 1, 1 and 2 setae; endopod segment 1 with 1 seta, endopod segment 2 with 5 setae, 2 of these very small.

Maxillule (Fig. 7J-K), praecoxal endite with 10 setae and small spinules present near base of 2 distal setae. Coxal endite with 3 setae and tiny denticles near base of setae; proximal basal endite with 1 long and 2 shorter setae; distal basal endite with 5 setae; endopod with 16 setae, of these 12 setae long and well sclerotized, 3 short and thin, and 1 small, vestigial; exopod with 11 setae; coxal epipodite with 9 setae.

Maxilla (Fig. 8A-B), praecoxal and coxal endites with 3 setae each; proximal basal endite with 3 setae of nearly same shape; distal basal endite with 1 seta, ramus with 5 setae, all well sclerotized. Praecoxal and coxal endites supplied with short surface spinules.

Maxilliped (Fig. 8C-E), syncoxa with 1 small seta on proximal praecoxal endite, 2 setae on middle endite, 3 setae and row of surface spinules between distal praecoxal and coxal endites; coxal endite with 3 setae and finger-like sensory appendage. Basis with 3 medial (1 broken) and 1 distal setae. Endopod 5-segmented with 4, 4, 3, 3+1 and 4 setae; 1 seta of terminal segment and lateral seta of penultimate segment very small, vestigial.

P1 (Fig. 6F-G), coxa without seta, basis with small distolateral seta, and medial distal seta strongly curved; endopod 1-segmented with well developed lateral lobe ornamented with denticles, and a group of denticles on anterior surface. Exopod segments 1, 2 and 3 with lateral spines each; spine of exopod segment 1 not reaching base of following spine, spine of exopod segment 2 reaching base of following spine. Spines of exopod segments 1 and 2 with short sparse hairs along inner border.

P2 (Fig. 8G), coxa with medial seta; basis without seta; endopod 2-segmented; exopod 3-segmented.

P3 (Fig. 8H), coxa with medial seta, basis without seta; endopod and exopod of 3 segments.

P4 (Fig. 8I), coxa apparently with seta broken, basis without seta, endopod and exopod of 3 segments.

Male unknown.

Etymology. The species epithet is given for the acute shape of posterior corners of the prosome. Gender masculine.

Remarks. Pseudeuchaeta includes 6 species $(P$. brevicauda Sars, 1905, P. major Wolfenden, 1911, P. flexuosa Bradford, 1969, P. magna Bradford, 1969, P. arctica Markhaseva, 1986, and P. spinata Markhaseva, 1986). To date only P. brevicauda has been recorded from the Southern Ocean (Park, 1978; Markhaseva, 1996).

Pseudeuchaeta acuticornis is distinguished from congeners by: i) presence of a lateral spine on P1 exopod segment 1 (character shared with $P$. spinata); ii) 5 setae on mandible endopod 2 (shared with P. major), $(3,4,7,8 / 9$ setae in other species of the genus); iv) 10 setae on maxillule praecoxal arthrite (shared with $P$. major; 11-13 setae in other congeners); v) 3 setae on maxillule coxal endite (shared with $P$. major; 2 or 4 setae in other species of Pseudeuchaeta); vi) the most primitive, incompletely 9-segmented antenna exopod is shared with $P$. flexuosa. Some other characteristics are listed in Table 2. The new species resembles the rather poorly described P. major, however, it differs in the presence of a lateral spine on P1 exopodal segment 1 , shape of the posterior corners of prosome and in setation of maxillule proximal basal endite (Table 2).

\section{Discussion}

Sewell (1947) and Grice (1972) emphasized the close relationship of Pseudeuchaeta and Bradyetes considering, however, a morphological difference between both genera in the presence of 1 enlarged seta on the proximal 


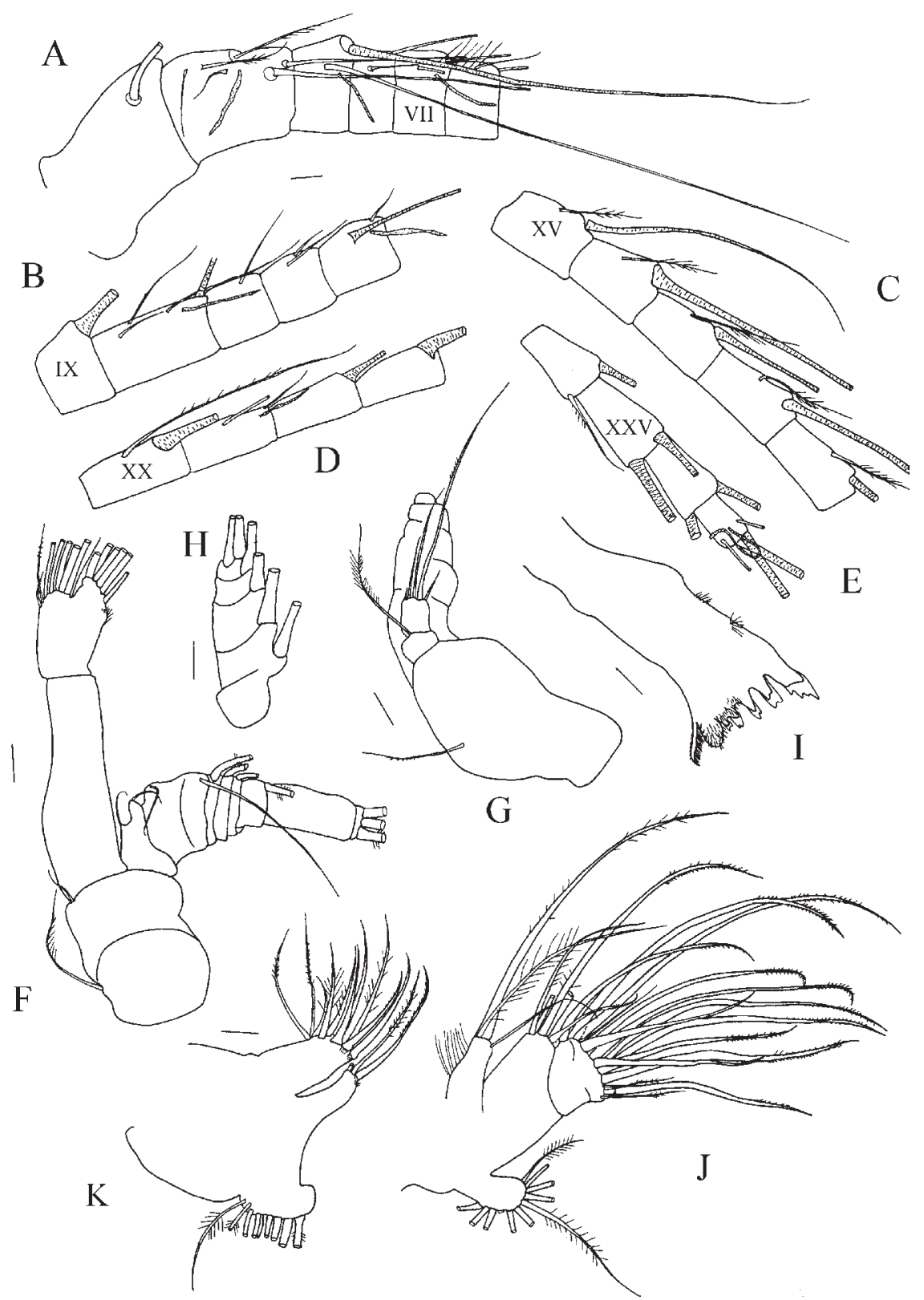

Fig. 7. Pseudeuchaeta acuticornis sp.n. Female, holotype.

A — antennule, segments I (1st) to VIII (6th); B — antennule, segments IX (7th) to XIV (11th); C — antennule, segments XV (12th) to XIX (16th); D — antennule, segments XX (17th) to XXIII (20th); E — antennule, segments XXIV (21st) to XXVIII (24th); F, antenna; $\mathrm{G}$ - mandibular palp; H — mandible, exopod; I - mandibular gnathobase; J - maxillule, basis, endopod and exopod (1 seta broken); $\mathrm{K}$ - maxillule, praecoxal arthrite, coxal endite and epipodite. Scales $0.1 \mathrm{~mm}$. Рис. 7. Pseudeuchaeta acuticornis sp.n. Самка, голотип.

A - антеннула, сегменты с I (первого) по VIII (6-й); В — антеннула, сегменты с IX (7-й) по XIV (11-й); C антеннула, сегменты с XV (12-го) по XIX (16-й); D - антеннула, сегменты с XX (17-го) по XXIII (20-й); E антеннула, сегменты с XXIV (21-го) по XXVIII (24-й); F, антенна; G — щупик мандибулы; H — мандибула, экзоподит; I — мандибула, гнатобаза; J — максиллула, базис, эндоподит и экзоподит (1 щетинка сломана); $\mathrm{K}$ максиллула, прекоксальный артрит, коксальный эндит и эпиподит. Масштаб 0,1 мм. 
New benthopelagic aetideids

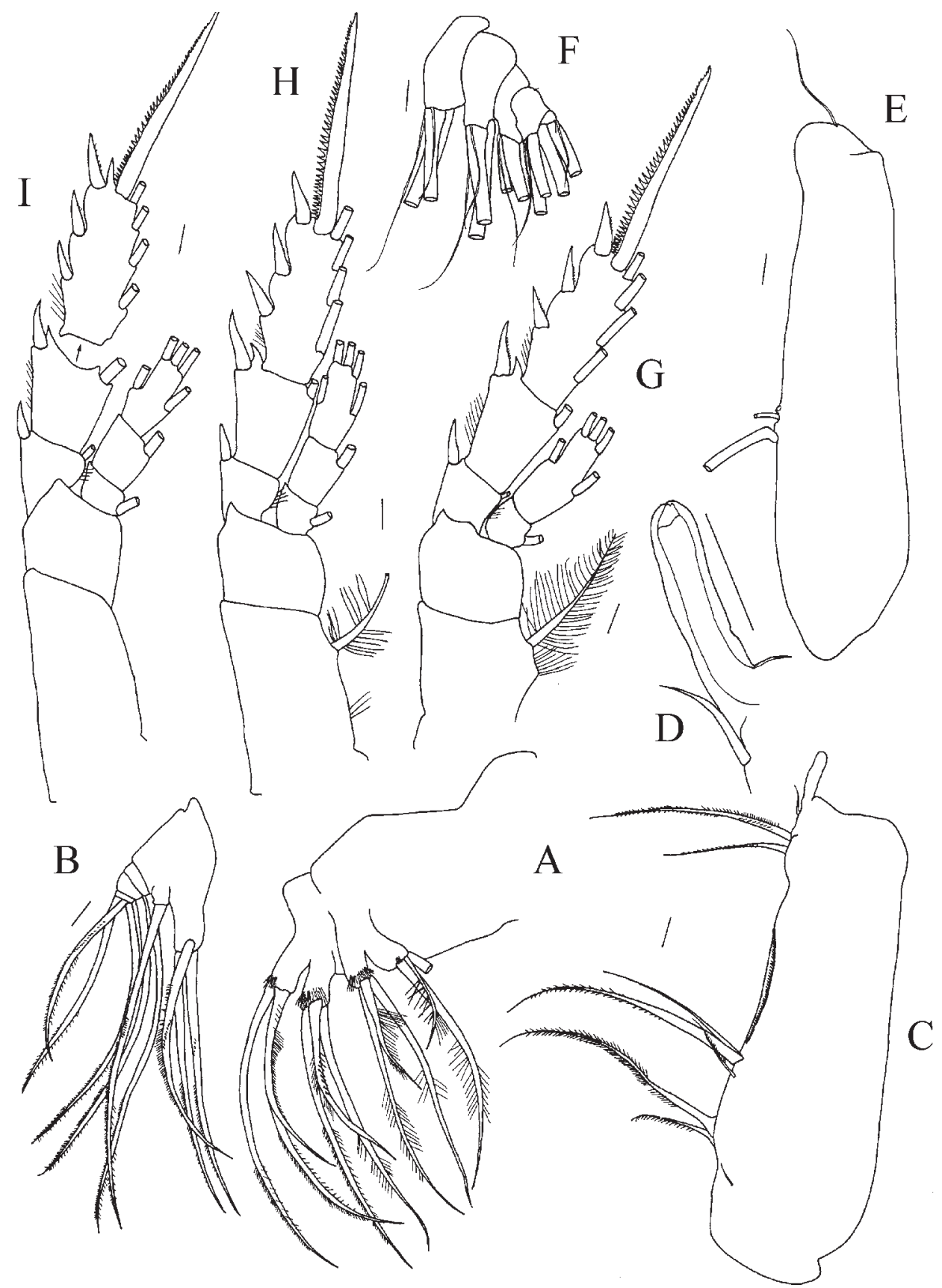

Fig. 8. Pseudeuchaeta acuticornis sp.n. Female, holotype.

A - maxilla, praecoxal and coxal endites; B — maxilla, basal endites and ramus; C — maxilliped, syncoxa; D — sensory appendage of coxal endite with adjacent seta; $\mathrm{E}$ - maxilliped, basis (1 seta broken); $\mathrm{F}$ - maxilliped, endopod; $\mathrm{G}$ P2; H- P3; I- P4. Scales $0.1 \mathrm{~mm}$.

Рис. 8. Pseudeuchaeta acuticornis sp.n. Самка, голотип.

A - максилла, прекоксальные и коксальные эндиты; В - максилла, базальные эндиты и ветвь; С максиллипеда, синкокса; D - сенсорный придаток коксального эндита с прилежащей щетинкой; Е - максиллипеда, базис (1 щетинка сломана); F - максиллипеда, эндоподит; G - P2; H - P3; I - P4. Масштаб 0,1 мм. 


\begin{tabular}{|c|c|c|c|}
\hline Character & B. inermis & B. cf. inermis & B. matthei \\
\hline Total length $(\mathrm{mm})$ & $2.57-3.20$ & 2.95 & $1.19-1.32$ \\
\hline Prosome/urosome ratio & - & 3.2 & - \\
\hline Cephalosome \& pedigerous somite 1 & partly separated & fused & partly separated \\
\hline Pedigerous somites $4 \& 5$ & fused & fused & partly separated \\
\hline Shape of posterior corners of prosome & rounded & rounded & pointed \\
\hline Posterior corners of prosome dorsally & not bifurcate & not bifurcate & not bifurcate \\
\hline Length of antennule & $\begin{array}{l}\text { slightly longer than } \\
\text { prosome }\end{array}$ & $\begin{array}{l}\text { exceeding posterior } \\
\text { border of genital } \\
\text { double-somite }\end{array}$ & $\begin{array}{l}\text { extending to } \\
\text { posterior border } \\
\text { of pediger } 3\end{array}$ \\
\hline Antenna: setation of coxa/basis/Enp1 & $1 / 1 / 2$ & $? / 2 / 2$ & $1 / 2 / 2$ \\
\hline $\begin{array}{l}\text { Presence and length of seta on } \\
\text { penultimate segment of antenna exopod }\end{array}$ & absent & absent & present, long \\
\hline Mandible: setation of basis/Enp1/Enp2 & $1 / 1 / 3$ & $1 / 1 / 4$ & $2 / 2 / 9$ \\
\hline $\begin{array}{l}\text { Maxillule: } \\
\text { setation of praecoxal endite } \\
\text { setation of coxal endite } \\
\text { setation of proximal basal endite setation } \\
\text { of distal basal endite setation of Enp } \\
\text { setation of Exp } \\
\text { setation of epipodite }\end{array}$ & - & $\begin{array}{c}10 \\
4 \\
3 \\
4 \\
12 \\
11 \\
7+?\end{array}$ & $\begin{array}{c}13 \\
5 \\
4 \\
5 \\
15 \\
10 \\
9\end{array}$ \\
\hline $\begin{array}{l}\text { Maxilla: setation of terminal part (distal } \\
\text { basal endite \& exopod) }\end{array}$ & ? & $6+2$ & 6 \\
\hline Maxilla: setation of proximal basal endite & $\begin{array}{l}1 \text { thin, short seta, } 1 \\
\text { longer seta, thick, } \\
\text { claw-like }+1 \text { thin } \\
\text { seta, the longest }\end{array}$ & $\begin{array}{l}1 \text { thin, short seta, } \\
1 \text { longer seta, thick, } \\
\text { claw-like }+1 \text { thin seta, } \\
\text { the longest }\end{array}$ & $\begin{array}{l}1 \text { thick claw-like } \\
\text { seta }+2 \text { thin } \\
\text { longer setae }\end{array}$ \\
\hline $\begin{array}{l}\text { Length of sensory appendage on coxal } \\
\text { endite of maxilliped syncoxa }\end{array}$ & $\begin{array}{l}\text { nearly as long as } \\
\text { longest distal seta }\end{array}$ & $\begin{array}{l}\text { nearly } 1.5 \text { times } \\
\text { length of longest } \\
\text { distal seta }\end{array}$ & $\begin{array}{l}\text { much shorter } \\
\text { than longest } \\
\text { distal seta }\end{array}$ \\
\hline P1 Enp lateral endite & $\begin{array}{l}\text { moderately/poorly } \\
\text { developed }\end{array}$ & poorly developed & well developed \\
\hline P1 Exp lateral spine 1 & $\begin{array}{l}\text { extending to distal } \\
\text { third of lateral spine } 2\end{array}$ & $\begin{array}{l}\text { extending to distal } \\
\text { third of lateral spine } 2\end{array}$ & $\begin{array}{l}\text { extending base } \\
\text { of lateral spine } 2\end{array}$ \\
\hline P1 Exp lateral spine 2 & $\begin{array}{l}\text { extending base of } \\
\text { lateral spine } 3\end{array}$ & $\begin{array}{l}\text { extending base of } \\
\text { lateral spine } 3\end{array}$ & $\begin{array}{l}\text { extending base } \\
\text { of lateral spine } 3\end{array}$ \\
\hline
\end{tabular}


Table 1. Selected character states of species included in Bradyetes (females). Таблица 1. Основные признаки, характеризующие виды, включенные в Bradyetes (по самкам).

\begin{tabular}{|c|c|c|}
\hline B. pacificus & B. weddellanus sp.n. & B. curvicornis sp. $\mathbf{n}$. \\
\hline $2.96-2.98$ & $4.75-5.50$ & 4.15 \\
\hline 3.4 & $2.6-2.9$ & 3.35 \\
\hline partly separated & fused & separate \\
\hline partly separated & fused & partly separated \\
\hline pointed & rounded & pointed \\
\hline bifurcate & not bifurcate & not bifurcate \\
\hline $\begin{array}{l}\text { extending to posterior border of } \\
\text { pediger } 3\end{array}$ & $\begin{array}{l}\text { nearly as long as prosome, or } \\
\text { exceeding prosome by distal } \\
\text { segment }\end{array}$ & $\begin{array}{l}\text { extending to posterior border of } \\
\text { genital somite }\end{array}$ \\
\hline $1 / 2 / 2$ & $1 / 2 / 2$ & $1 / 2 / 2$ \\
\hline present, long & present, vestigial & present, vestigial \\
\hline $1 / 0 / 4$ & $1 / 1 / 4$ & $1 / 1 / 5$ \\
\hline $\begin{array}{c}13 \\
4 \\
3 \\
4 \\
12 \\
11 \\
6\end{array}$ & $\begin{array}{c}11 \\
4 \\
3 \\
4 \\
12 \\
11 \\
9\end{array}$ & $\begin{array}{c}11 \\
4 \\
3 \\
4 \\
14 \\
11 \\
9\end{array}$ \\
\hline $6+2$ & $6+2$ & $6+2$ \\
\hline $\begin{array}{l}1 \text { thin, short seta, } 1 \text { longer seta, } \\
\text { thick, claw-like }+1 \text { seta, the longest }\end{array}$ & $\begin{array}{l}1 \text { thin, short seta, } 1 \text { longer seta, } \\
\text { thick, claw-like }+1 \text { thin seta, the } \\
\text { longest }\end{array}$ & $\begin{array}{l}1 \text { thin, short seta, } 1 \text { longer seta, } \\
\text { thick, claw-like }+1 \text { thin seta, the } \\
\text { longest }\end{array}$ \\
\hline $\begin{array}{l}\text { more than twice length of longest } \\
\text { distal seta }\end{array}$ & $\begin{array}{l}\text { about } 6 \text { times shorter than longest } \\
\text { distal seta }\end{array}$ & $\begin{array}{l}\text { about } 3 \text { times length of longest } \\
\text { distal seta }\end{array}$ \\
\hline well developed & moderately or poorly developed & well developed \\
\hline $\begin{array}{l}\text { extending to distal third of lateral } \\
\text { spine } 2\end{array}$ & $\begin{array}{l}\text { nearly to mid-length of lateral } \\
\text { spine } 2\end{array}$ & $\begin{array}{l}\text { apparently extending to the distal } \\
\text { third of lateral spine } 2\end{array}$ \\
\hline extending base of lateral spine 3 & $\begin{array}{l}\text { not reaching base of lateral } \\
\text { segment } 3\end{array}$ & $\begin{array}{l}\text { slightly extending base of lateral } \\
\text { spine } 3\end{array}$ \\
\hline 0.85 & 1.04 & about 1.2 \\
\hline
\end{tabular}




\begin{tabular}{|l|l|l|l|l|}
\hline P3 Exp 2 and Exp 1, lateral spines length & - & $\begin{array}{l}\text { Exp2 about 1.5 times } \\
\text { longer }\end{array}$ & $\begin{array}{l}\text { Exp2 about } 1.4 \\
\text { times longer }\end{array}$ & \\
\hline
\end{tabular}

\begin{tabular}{|c|c|c|c|}
\hline Character & P. arctica & P. brevicauda & P. flexuosa \\
\hline Total length (mm) & $10.30-10.50$ & $4.80-6.58$ & 6.8 \\
\hline Prosome/urosome ratio & $2.8-3.0$ & $3.4-3.9$ & 3.5 \\
\hline $\begin{array}{l}\text { Cephalosome \& pedigerous } \\
\text { somite } 1\end{array}$ & partly fused & separate & partly fused \\
\hline Pedigerous somites $4 \& 5$ & partly fused & separate & partly fused \\
\hline $\begin{array}{l}\text { Shape of posterior corners of } \\
\text { prosome, lateral view }\end{array}$ & $\begin{array}{l}\text { pointed, directed } \\
\text { slightly upwards }\end{array}$ & rounded-triangular & $\begin{array}{l}\text { pointed, directed } \\
\text { upwards }\end{array}$ \\
\hline Length of antennule & $\begin{array}{l}\text { about as long as } \\
\text { prosome }\end{array}$ & $\begin{array}{l}\text { extending to anterior } \\
\text { border or to the end of } \\
\text { pedigerous somite } 5\end{array}$ & shorter than prosome \\
\hline $\begin{array}{l}\text { Presence of seta on penultimate } \\
\text { segment of antenna exopod }\end{array}$ & present & absent & absent \\
\hline $\begin{array}{l}\text { Antenna: setation of } \\
\text { coxa/basis/Enp1 }\end{array}$ & $1 / 1 / 0$ & $1 / 1 / 0$ & $1 / 1 / 0$ \\
\hline $\begin{array}{l}\text { Mandible: seation of } \\
\text { basis/Enp1/Enp2 }\end{array}$ & $1 / 1 / 8$ & $1 / 1 / 8-9$ & $1 / 1 / 7$ \\
\hline $\begin{array}{l}\text { Maxullule: } \\
\text { setation of praecoxal endite } \\
\text { setation of coxal endite } \\
\text { setation of proximal basal endite } \\
\text { setation of distal basal endite } \\
\text { setation of Enp } \\
\text { setation of Exp } \\
\text { setation of epipodite }\end{array}$ & $\begin{array}{c}12 \\
4 \\
3 \\
5 \\
15 \\
11 \\
9\end{array}$ & $\begin{array}{c}13 \\
4 \\
3 \\
5 \\
13-14 \\
11 \\
8\end{array}$ & $\begin{array}{c}? \\
4 \\
3 \\
5 \\
14 \\
11 \\
9\end{array}$ \\
\hline $\begin{array}{l}\text { Maxilla : setation of terminal } \\
\text { part (distal basal endite } \& \\
\text { exopod) }\end{array}$ & 6 & 6 & 6 \\
\hline $\begin{array}{l}\text { Maxilla: setae on proximal basal } \\
\text { endite }\end{array}$ & $\begin{array}{l}\text { similar shape and } \\
\text { length }\end{array}$ & similar shape and length & $\begin{array}{l}\text { ? similar shape and } \\
\text { length }\end{array}$ \\
\hline $\begin{array}{l}\text { Length of sensory appendage on } \\
\text { coxal endite of maxilliped } \\
\text { syncoxa }\end{array}$ & shorter than distal setae & $\begin{array}{l}\text { shorter than longest distal } \\
\text { seta }\end{array}$ & $\begin{array}{l}\text { shorter than distal } \\
\text { setae }\end{array}$ \\
\hline P1 Exp lateral spine 1 & absent & absent & absent \\
\hline
\end{tabular}


Table 1 (continuing). Таблица 1 (продолжение).

\begin{tabular}{|l|l|l|c|}
\hline & Exp2 about 2 times longer & Exp2 ca. 2.4 times longer & Exp2 ca. 2.4 times longer \\
\hline
\end{tabular}

Table 2. Selected character states of species included in Pseudeuchaeta (females). Таблица 2. Основные признаки, характеризующие виды, включенные в Pseudeuchaeta (по

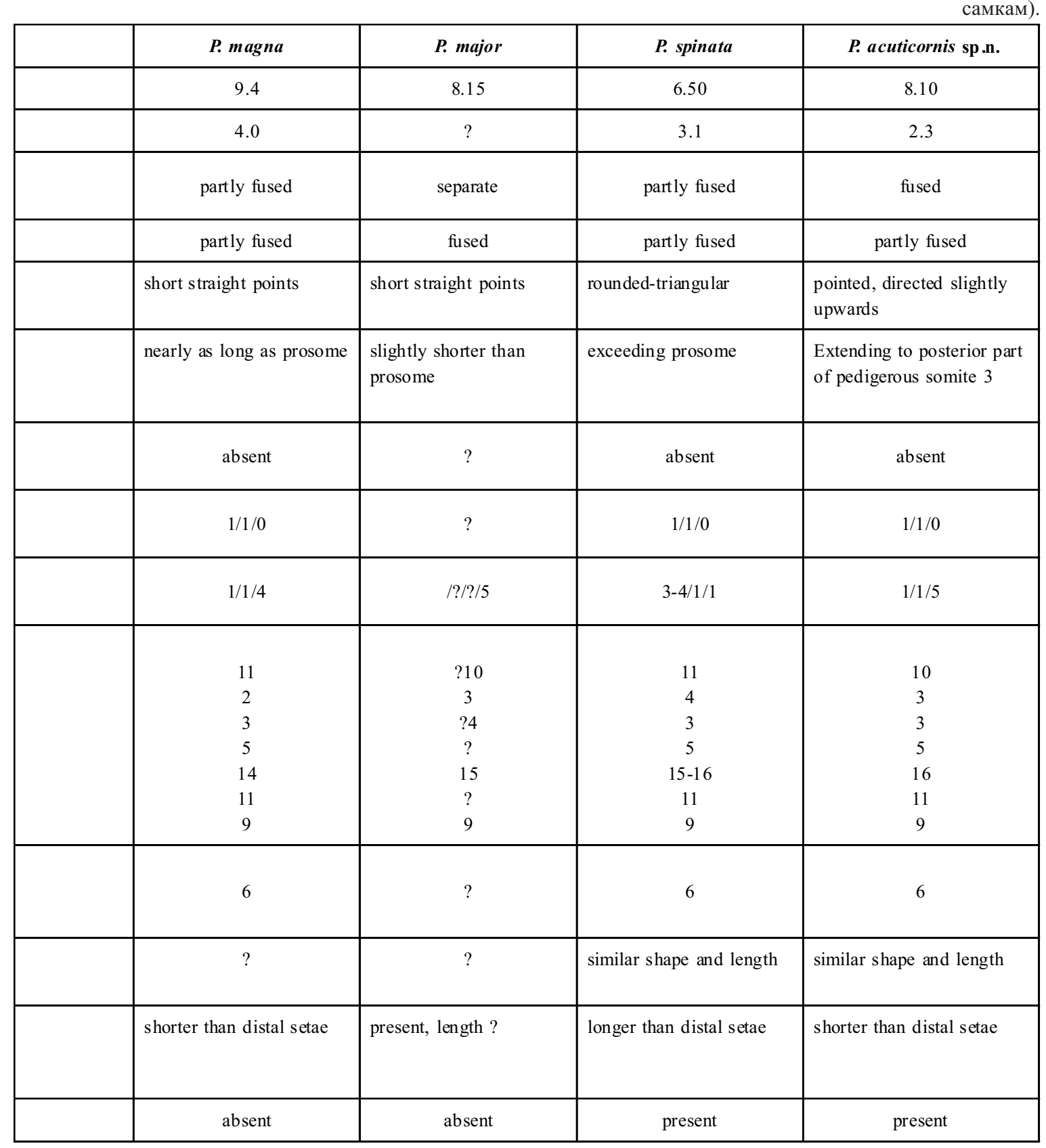


basal endite of maxilla and "the setae on the distal end of maxilliped normal" in Bradyetes, while in Pseudeuchaeta although none of these setae is enlarged "the distal setae of the maxilliped have transverse lamellae" (Grice, 1972: 234). Some additional characters distinguishing these genera are proposed below and in Tables 1, 2.

Pseudeuchaeta, apparently, appears to be a more derived genus than Bradyetes on account of: i) antenna basis with 1 seta ( 2 setae in the latter, except for B. inermis, see Table 1); ii) antenna endopod segment 1 without seta ( 2 setae in Bradyetes); iii) maxilla distal basal endite plus ramus with 6 setae (6 plus 2 small setae in Bradyetes, except for B. matthei, see Table 1).

Further, maxillule endopod, maxilla, and maxilliped of Pseudeuchaeta are marked by robust setae (Figs 6B, 7J, 8A-B) that are typical of predatory copepods.

However, among Aetideidae both Bradyetes and Pseudeuchaeta share a most primitive antennal segmentation pattern of the proximal exopodal segments: 2 segments are fused to form the most proximal segment in a compound segment bearing 2 setae (Fig. 7F), following 2 proximal segments in primitive state are incompletely separate (B. inermis see Grice, 1972, Fig. 4, P. flexuosa Bradford, 1969 see Fig. 109 and $P$. acuticornis sp.n.) each bearing 1 seta, but in derived state in these genera they are fused in a compound segment bearing 2 setae. The similar fusion pattern is true of Crassantenna mimorostrata Bradford, 1969, Sursamucro spinatus Bradford, 1969, Paracomantenna goi Ohtsuka, Boxshall et Shimomura, 2005 and Jaschnovia Markhaseva, 1996, where the two most proximal segments of antenna are compound segments: each bearing 2 setae. In all remaining aetideids the most proximal segment is not compound but the following segment is a compound segment of 3 or even 4 fused segments (see Park, 1978; Markhaseva, 1993, 1996; Schulz, Markhaseva, 2000; Schulz, 2002) resulting in a large segment complex, a morphological pattern highly comparable to that established in bradfordian families of Clausocalanoidea and analyzed by Markhaseva et Ferrari (2005: 160, Fig. 30).

\section{Acknowledgements}

The authors thank Prof. Angelika Brandt for providing the sorted copepod fraction of ANDEEP I-III expeditions which yielded the specimens analyzed in this paper. Research of E.L. Markhaseva at Deutsches Zentrum fuer Marine Biodiversitaetsforschung (DZMB), Senckenberg, Biozentrum Grindel \& Zoologisches Museum Hamburg (ZMH) was funded by Deutsche Forschungsgemeinschaft (DFG) (GZ 436RUS17/129/05). This is ANDEEP publication \# 55.

\section{Literature}

Bradford J.M. 1969. New genera and species of the benthic calanoid copepods from the New Zealand slopes // New Zealand Journal of Marine and Freshwater Research. Vol.3. No.4. P.473-505.

Bradford J.M., Wells J.B.J. 1983. New calanoid and harpacticoid copepods from beneath the Ross Ice Shelf, Antarctica // Polar Biology. Vol.2. P.1-15.

Brandt A., Barthel D. 1995. An improved supra- and epibenthic sledge for catching Peracarida (Crustacea, Malacostraca) // Ophelia. Vol.43. P.15-23.

Brandt A., De Broyer C., Gooday A.J., Hilbig B., Thomson M.R.A. 2004. Introduction to ANDEEP (Antarctic benthic DEEP-sea biodiversity: colonization history and recent community patterns) - atribute to Howard L. Sanders // Deep-Sea Research. Vol.51. P.1457-1465.

Farran G.P. 1905. Report on the Copepoda of the Atlantic slope off counties Mayo and Galway // Annual Report Fisheries Ireland 1902-1903. Appendix 2. P.23-52.

Ferrari F.D., Ivanenko V.N. 2001. Interpreting segment homologies of the maxilliped of cyclopoid copepods by comparing stage-specific changes during development // Organisms, Diversity and Evolution. Vol.1. P.113-131.

Ferrari F.D., Markhaseva E.L.2000a. Brachycalanus flemingeri and B. brodskyi, two new copepods (Crustacea: Calanoida: Phaennidae) from benthopelagic waters of the tropical Pacific // Proceedings of the Biological Society of Washington. Vol.113. P.1064-1078.

Ferrari F.D., Markhaseva E.L. 2000b. Grievella shanki, a new genus and species of scolecitrichid calanoid copepod (Crustacea) from a hydrothermal vent along the southern East Pacific Rise // Proceedings of the Biological Society of Washington. Vol.113. P.1079-1088.

Grice G.D. 1972. The existence of a bottom-living calanoid copepod fauna in deep water with descriptions of five new species // Crustaceana. Vol.23. P.219-242.

Johannessen P.J. 1976. A new species and a new record of calanoid copepods from western Norway // Sarsia. Vol.60. P.19-24. 
Markhaseva E.L. 1986. New species of the genus Pseudeuchaeta (Calanoida, Aetideidae) from the Arctic and Pacific Oceans with notes on geographical distribution of $P$. brevicauda // Zoologicheskii Zhurnal. Vol.65. No.12. P.1892-1898 [in Russian].

Markhaseva E.L. 1993. Two new species of Bradyidius with notes on $B$. armatus Giesbrecht (Crustacea, Copepoda: Aetideidae) // Zoosystematica Rossica. Vol.2. No.1. P.47-53.

Markhaseva E.L. 1996. Calanoid copepods of the family Aetideidae of the world ocean // Trudy Zoologicheskogo Instituta RAN. Vol.268. 331 p.

Markhaseva E.L., Dahms H.-U. 2004. Plesioscolecithrix (Copepoda, Calanoida, Scolecitrichidae): new genus and new species from the high Antarctic Weddell Sea (Southern Ocean) // Sarsia. Vol.89. P.326-337.

Markhaseva E.L., Ferrari F.D. 2005. New benthopelagic bradfordian calanoids (Crustacea: Copepoda) from the Pacific Ocean with comments on generic relationships // Invertebrate Zooology. Vol.2. No.2. P.111-168.

Ohtsuka S., Takeuchi I., Tanimura A. 1998. Xanthocalanus gracilis and Tharybis magna (Copepoda, Calanoida) rediscovered from the Antarctic Ocean with baited traps // Journal of Natural History. Vol.32. P.785-804.

Ohtsuka S., Boxshall G.A., Shimomura M. 2005. Three new species of deep-sea hyperbenthic aetideid copepods (Crustacea) collected from Nansei Islands, Southwestern Japan // Hasegawa K., Shinohara G., Takeda M. (eds). Deep-sea fauna and pollutants in Nansei Islands. National Science Museum Monographs. Tokyo. No.29. P.225-247.

Park T.S. 1978. Calanoid copepods (Aetideidae and Euchaetidae) from Antarctic and subantarctic waters. Biology of the Antactic Seas, 7. Antarctic Research Series. Vol.27. P.91-290.

Sars G.O. 1905. Liste préliminaire des Calanoides recueillis pendant les campagnes d S.A.S. le Prince Albert de Monaco, avec diagnoses genres et espèces nouvelles (1-er partie) // Bulletin de 1'Institut Océanographique. Monaco. Vol.26. P.1-22.

Schulz K. 1996. Frigocalanus rauscherti, a new genus and species of hyperbenthic copepod (Calanoida: Clausocalanoidea) from the sublittoral of King George Island (Antarctica) // Mitteilungen aus dem Hamburgischen Zoologischen Museum und Institut. Vol.93. P.73-82.

Schulz K. 1998. A new species of Xantharus Andronov, 1981 (Copepoda: Calanoida) from the mesopelagic zone of the Antarctic Ocean // Helgolaender Meeresuntersuchungen. Vol.52. P.41-49.

Schulz K. 2002. A new species of the hyperbenthic copepod genus Comantenna Wilson, 1924 (Calanoida: Aetideidae) from the eastern Weddell Sea // Mitteilungen aus dem Hamburgischen Zoologischen Museum und Institut. Vol.99. P.101-107.

Schulz K. 2005. A new species of benthopelagic copepods (Crustacea, Calanoida) from the deep Southern Ocean // Mitteilungen aus dem Hamburgischen Zoologischen Museum und Institut. Vol.102. P.51-70.

Schulz K., Markhaseva E.L. 2000. Parabradyidius angelikae, a new genus and species of benthopelagic copepod (Calanoida: Aetideidae) from the deep Weddell Sea (Antarctica) // Mitteilungen aus dem Hamburgischen Zoologischen Museum und Institut. Vol.97. P.77-89.

Sewell R.B.S. 1947. The free-swimming planktonic Copepoda. Systematic account // Scientific Reports John Murrey Expedition. Vol.8. 303 p.

Vives F. 1982. Sur les copépodes de la région CINECA (parties nord et centrale)//G. Hempel (ed.). The Canary Current: studies of an upwelling system. A symposium held in Las Palmas. 11-14 April 1978. Rapport et Procès-Verbaux des Rèunions, Conseil International pour L'exploration de la mer. 180. P.289-296.

Wolfenden R.N. 1911. Die marinen Copepoden der Deutschen Sudpolar Expedition 1901-1903 // Deutsche Sudpolar Exped. 7 (zool.). Vol.4. P.181-380. 